\title{
Effect of Water Activity, Yuza (Citrus junos Sieb. ex Tanaka) Powder and the Mixture of Sodium Lactate and Sodium Acetate on Quality and Safety in Beef Jerky
}

\author{
Yeon Ho Kim, Ju Young Lim, Ki Sun Yoon* \\ Department of Food and Nutrition, Kyung Hee University, Seoul, Republic of Korea \\ Email: *ksyoon@khu.ac.kr
}

How to cite this paper: Kim, Y.H., Lim, J.Y. and Yoon, K.S. (2019) Effect of Water Activity, Yuza (Citrus junos Sieb. ex Tanaka) Powder and the Mixture of Sodium Lactate and Sodium Acetate on Quality and Safety in Beef Jerky. Food and Nutrition Sciences, 10, 588-605.

https://doi.org/10.4236/fns.2019.106043

Received: May 7, 2019

Accepted: June 11, 2019

Published: June 14, 2019

Copyright $\odot 2019$ by author(s) and Scientific Research Publishing Inc. This work is licensed under the Creative Commons Attribution International License (CC BY 4.0).

http://creativecommons.org/licenses/by/4.0/

(c) (i) Open Access

\begin{abstract}
Despite its low water activity $\left(A_{w}\right)$, food poisoning accidents associated with beef jerky consumption and problems due to mold growth have been reported. The objects of this study were to investigate the effect of yuza powder and the mixture of sodium lactate (SL) and sodium acetate (SA) to prevent the growth of $S$. aureus and A. flavus, as well as aflatoxin production in beef jerky. Different concentrations of the SL and SA $(0,0.75$, and $1 \%)$ mixture were added to sliced beef and the $\mathrm{A}_{\mathrm{w}} \mathrm{s}$ were adjusted to 0.70, 0.75 , and 0.80 . The effect of yuza powder and the SL and SA mixture on $S$. aureus in beef jerky $\left(\mathrm{A}_{\mathrm{w}} 0.80\right)$ was also investigated at $10^{\circ} \mathrm{C}$ and $25^{\circ} \mathrm{C}$. A rapid decline is that $S$. aureus population was observed in beef jerky containing yuza powder and mixtures of SL and SA. Antifungal effects against $A$. flavus were observed in beef jerky containing the SL and SA mixture at $\mathrm{A}_{\mathrm{w}}$ below 0.75 . The growth of $A$. flavus and aflatoxin production were prevented in beef jerky containing the yuza powder and a $1 \%$ mixture of SL and $\mathrm{SA}$ at $10^{\circ} \mathrm{C}$ and $0.80 \mathrm{~A}_{\mathrm{w}}$. The addition of yuza powder increased the hardness score of the beef jerky. Under current $\mathrm{A}_{\mathrm{w}}$ regulations (0.80), beef jerky may pose a public health risk due to the growth of $A$. flavus and the presence of aflatoxin.
\end{abstract}

\section{Keywords}

Beef Jerky, Yuza, Staphylococcus aureus, Aspergillus flavus, Aflatoxin

\section{Introduction}

Beef jerky is a popular snack in many countries. Recently, various jerky products with different types of meats and seasonings have been introduced in on- and 
off-line markets and they have become popular snack items in Korea. Beef jerky is one of the oldest traditional foods and is prepared by simple processing, such as drying and salting [1]. However, no regulations govern the safety of beef jerky in Korea because it has been considered to be a safe food. The water activity $\left(\mathrm{A}_{\mathrm{w})}\right.$ of jerky products in Korea ranges from 0.70 to 0.88 [2], while the US Department of Agriculture (USDA) regulates maximum water activity of jerky products at 0.80 [3]. Despite the low $A_{w}$, over 250 cases of accidental food poisoning associated with the consumption of jerky were reported between 1966 and 2003 [4]. E. coli O157: H7, Listeria monocytogenes, Staphylococcus aureus, and several Salmonella strains [5] [6] were implicated as causative bacteria. A recent study reported the growth of Staphylococcus aureus on beef jerky $\left(\mathrm{A}_{\mathrm{w}} 0.78\right)$ at temperatures above $21^{\circ} \mathrm{C}$ [7]. Jerky products are associated; not only foodborne outbreaks but also with spoilage problems resulting from mold growth [8].

In the jerky industry, mold is a more serious problem than bacteria (personal communication). Aspergillus flavus was reported in Spanish dried-cured ham and, thus, produced aflatoxin [9]. In order to control the mold, beef jerky was exposed to $0.47 \mathrm{kGy}$ radiation [10]. Nitrites and sodium chloride are commonly used to prepare beef jerky. However, nitrites do not control the growth of fungi [11] and the addition of sodium chloride may cause many health problems, so low-sodium preparation methods have been explored.

Yuza (Citrus junos Sieb. ex Tanaka) is mainly cultivated in Korea, Japan, and China and is a citrus fruit [12]. Unlike oranges, grapefruit, and lemons, the peel, as well as the flesh of yuza, can be used as food ingredients. Yuza is consumed with tea, where the sliced yuza peel and flesh are sugared and made into a marmalade-like syrup sweetener. Currently, yuza has received attention as a healthy food ingredient from natural plants. Yuza fruit contains vitamin C, dietary fiber, beta-carotene, flavonoids, and limonoids, which cause a bitter taste. New product development efforts using yuza's peel and flesh residue have been reported [13]. The antimicrobial effects of other citrus fruits, such as grapefruit [14] and oranges [15] have also been reported. But yuza's antimicrobial and antifungal effects have not yet been investigated.

Opti.Form Powder Ace S50 contains a 5:5 mixture of sodium lactate (SL) and sodium acetate (SA), produced by fermentation from sugar. It is also known to extend the shelf life of meat products [16]. Various concentrations of sodium (di) acetate and sodium lactate mixtures have been used to prevent spoilage and the growth of pathogenic bacteria in meat products [17] [18]. Lactate alone $(1.5 \%$ to $3 \%)$ or in a mixture of $0.125 \%$ to $0.25 \%$ diacetate (wt/wt) has been used in ready-to-eat (RTE) meats as antimicrobial additives [19].

In this work, we investigated the effects yuza powder and the mixture of sodium lactate and sodium acetate on the physicochemical, antimicrobial, antifungal, and aflatoxin-inhibiting properties of beef jerky as functions of $A_{w}$ and temperature. 


\section{Materials and Methods}

\subsection{Preparation of Dried Yuza Powder}

Yuza was purchased in Corporation StoreFarm (Goheung, Korea) and washed with tap water. The washed yuza was cut in half and was squeezed to exclude juice. Then, the squeezed yuza halves were dried in a dried oven (HFD-6000HL, Hanil, Seoul, Korea) at $55^{\circ} \mathrm{C}$ for $24 \mathrm{~h}$. Dried yuza was grounded in a blender (HR2870/00, Philips, Armsterdam, Netherland) as a powder, which was stored at $-20^{\circ} \mathrm{C}$ until it is being used.

\subsection{Inoculum Preparation}

The Staphylococcus aureus (ATCC 13565) strain used was purchased from the Korean Culture Center of Microorganisms (KCCM, Seoul, Korea) and kept at $-80^{\circ} \mathrm{C}$ in tryptic soy broth (TSB, Difco, Becton Dickinson, Sparks, MD, USA) containing $20 \%$ glycerol. For the experiments, $10 \mu \mathrm{L}$ of thawed stock culture was inoculated into $10 \mathrm{~mL}$ of sterilized TSB and was incubated at $35^{\circ} \mathrm{C}$ for $24 \mathrm{~h}$ on a rotary shaker (VS-8480SR, Vision, Seoul, Korea) at $140 \mathrm{rpm}$. One milliliter of stationary phase $S$. aureus was diluted into $9 \mathrm{~mL}$ of $0.1 \%$ sterilized peptone water (Difco) before inoculation onto beef jerky.

Aspergillus flavus (KCCM 11453) was also purchased from KCCM. The strain was stored at $-20^{\circ} \mathrm{C}$ in a mixed solution of sterilized distilled water containing $10 \%$ glycerol. The culture was placed in $45 \mathrm{~mL}$ of potato dextrose broth (PDB, Difco) at $25^{\circ} \mathrm{C}$ for seven days on a rotary shaker (VS-8480SR, Vision, Seoul, Korea) at $140 \mathrm{rpm}$. Culture suspension $(100 \mu \mathrm{L})$ in PDB was inoculated on potato dextrose agar (PDA, Difco) and stored in an incubator (VS-1203P4S, Vision, Seoul, Korea) at $25^{\circ} \mathrm{C}$ for seven days.

\subsection{Preparation of Beef Jerky}

Sliced beef ( $0.7 \mathrm{~cm}$ thickness) was purchased from a local market (MangWon market, Seoul, Korea) and marinated with $15 \%$ sugar and $10 \%$ soy sauce with 0 (control) or $1.5 \%$ yuza powder. Then, 0.75 or $1 \%$ of the $5: 5$ mixture of sodium lactate and sodium acetate (Opmti. Form Powder Ace S50) (Corbion Purac, Amsterdam, Netherlands) was added to the marinated sliced beef with $0 \%$ yuza powder (BJ), $1.5 \%$ yuza powder (YBJ), $0.75 \% \mathrm{SL}+\mathrm{SA}$ with $0 \%$ yuza powder $(0.75 \mathrm{BJ}), 1 \% \mathrm{SL}+\mathrm{SA}$ with $0 \%$ yuza powder $(1 \mathrm{BJ}), 0.75 \% \mathrm{SL}+\mathrm{SA}$ with $1.5 \%$ yuza powder $(0.75 \mathrm{YBJ})$, or $1 \% \mathrm{SL}+\mathrm{SA}$ with $1.5 \%$ yuza powder (1 YBJ). All samples were stored overnight in the refrigerator. In order to investigate the effect of $A_{w}$ on the safety of beef jerky, $0.75 \mathrm{BJ}$ and $1 \mathrm{BJ}$ were placed in hot air dryer (HFD-6000HL, Hanil, Seoul, Korea) to adjust $A_{w}$ into 0.80, 0.75 , and 0.70 , respectively. On the other hand, $A_{w}$ of beef jerky marinated with $1.5 \%$ yuza powder was adjusted to 0.80 . Then, the beef jerky was cooled to room temperature. The preparation step for beef jerky is summarized in Figure 1. 


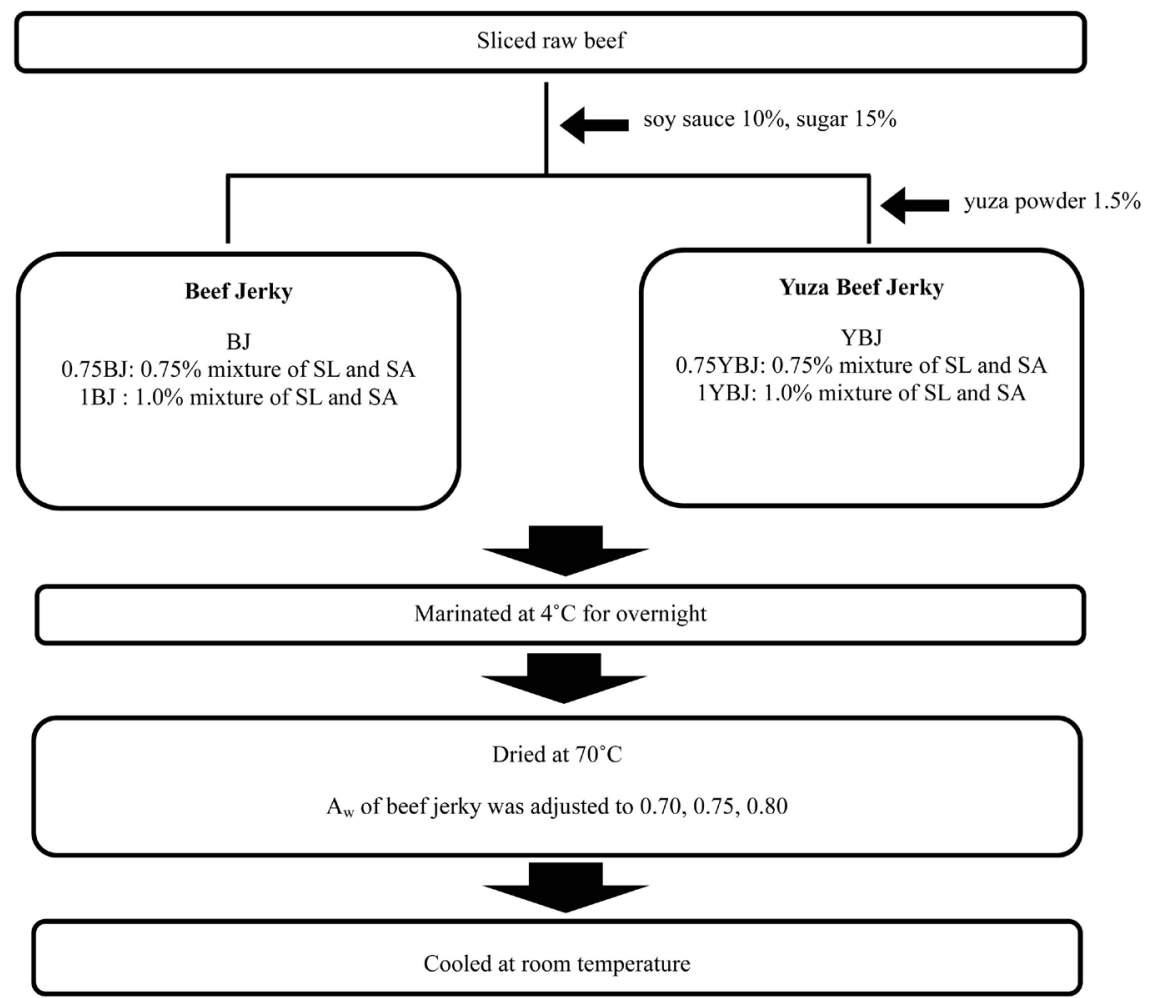

Figure 1. Flow chart of process for beef jerky containing yuza powder and the mixture of sodium lactate (SL) and sodium acetate (SA).

\subsection{Inoculation of $S$, aureus and A. flavus onto Beef Jerky}

Beef jerky was cut into $5 \mathrm{~g}$ pieces using sterilized scissors and forceps and put into sterilized Petri dishes $(60 \times 15 \mathrm{~mm})$. Diluted $S$. aureus culture $(25 \mu \mathrm{L})$ was evenly inoculated twice onto the surface of the beef jerky using an electronic pipet (MPA-200, A \& D Company, Tokyo, Japan). The initial level of $S$. aureus in the beef jerky was approximately $4 \log \mathrm{CFU} / \mathrm{g}$. The inoculated beef jerky was stored at $10^{\circ} \mathrm{C}$ and $25^{\circ} \mathrm{C}$.

A mixture of $1 \mathrm{~mL} 0.1 \%$ Tween 80 solution and $5 \mathrm{~mL}$ sterilized distilled water was added to fully grown $A$. flavus on PDA media. Then, the spores were scraped and washed using a sterilized loop and the numbers of spores per $\mathrm{mL}$ were counted using YM 3M Petrifilm (3M Corporation, St Paul, MN, USA). The concentration of the spores was approximately $6-7 \log$ CFU spores $/ \mathrm{mL}$. The diluted A. flavus spore solution was inoculated onto the surface of the beef jerky evenly using an electronic pipet at a final concentration of $4-5 \log \mathrm{CFU} / \mathrm{g}$ and the beef jerky was stored at $10^{\circ} \mathrm{C}$ and $25^{\circ} \mathrm{C}$ for eight weeks and four weeks, respectively. The spores were counted every week using YM 3M Petrifilm.

\subsection{Survival Model}

The survival curves were generated and iteratively fitted to the Weibull equation using a GinaFiT V 1.5 program (Geeraerd and Van Impe Inactivation Model Fitting Tool). 
Weibull model:

$$
\log _{10}(N)=\log _{10}\left(N_{0}\right)-(t / \text { delta })^{p}
$$

$N_{0}: \log$ initial number of cells, $t$ time

The Weibull model provides two parameters: delta which is referred to as a characteristic of time parameter and $p$ is the shape parameter. The delta value is the time of the first decimal reduction concentration for part of the population. A $p$ value $<1$ indicates a concave upward survival curve and $p>1$ is a concave downward survival curve. If $p=1$, the decrease is log-linear, which corresponds to a first-order decay reaction [20].

\subsection{Effect of Yuza Powder on the Inhibition of Aflatoxin Production}

A. flavus solution $(100 \mu \mathrm{L})$ at a concentration of $10^{6}-10^{7}$ spores $/ \mathrm{mL}$ was inoculated into beef jerky samples, which were either stored at $10^{\circ} \mathrm{C}$ for eight weeks or at $25^{\circ} \mathrm{C}$ for four weeks. At the end of each storage period, $25 \mathrm{~mL}$ of $70 \%$ methanol was added to $5 \mathrm{~g}$ of each sample, which was shaken on a rotary shaker at 140 rpm during 15 minutes. Then, the total aflatoxin quantity was estimated using the AgraQuant Aflatoxin Test Kit (Romer Labs, Getzersdorf, Austria).

\subsection{Water Activity $\left(A_{w}\right)$}

The water activity $\left(\mathrm{A}_{\mathrm{w}}\right)$ of beef jerky was measured using a waster activity meter (AwTherm Rotronic, Hauppaugue, NY, USA) at $23^{\circ} \mathrm{C}$.

\subsection{Instrumental Color Analysis}

For color analysis of the beef jerky, the values of $a^{*}$ (redness), $b^{*}$ (yellowness), and $L^{\star}$ (lightness) were measured using a colorimeter (Minolta CR-400, Osaka, Japan). Before sample measurements, the colorimeter was calibrated with a white standardization plate. All samples were cut into rectangular shapes $(5 \times 5$ $\mathrm{cm})$. The color of beef jerky was measured at five different parts of the sample.

\subsection{Texture Profile Analysis}

The beef jerky was cut into pieces $(10 \times 10 \times 3 \mathrm{~mm})$ and the texture was measured using a texture analyzer (CT-10K, Brookfield, Middleboro, MA, USA). A TA7 knife edge $(60 \mathrm{~mm})$ was used as a probe. Conditions for the texture profile analysis (TPA) of beef jerky were $2.0 \mathrm{~mm} / \mathrm{s}$ for pre-test speed, $1.0 \mathrm{~mm} / \mathrm{s}$ for test speed, and $5.0 \mathrm{~mm} / \mathrm{s}$ for post-test speed with $70 \%$ deformation of the test target type and $10 \mathrm{~g}$ of trigger load. Texture profile analysis values, such as hardness, adhesiveness, cohesiveness, springiness, chewiness, and gumminess, were measured as described by the Bourne method [21].

\subsection{Sensory Evaluation}

In order to study the effect of yuza powder and the mixture of SL and SA on beef jerky, four kinds of beef jerky were prepared for sensory evaluation: $0.75 \mathrm{BJ}$ 
$(0.75 \% \mathrm{SL}+\mathrm{SA}$ with $0 \%$ yuza powder $), 1 \mathrm{BJ}$ ( $1 \% \mathrm{SL}+\mathrm{SA}$ with $0 \%$ yuza powder $)$, $0.75 \mathrm{YBJ}$ (0.75\% SL + SA with $1.5 \%$ yuza powder), and $1 \mathrm{YBJ}(1 \% \mathrm{SL}+\mathrm{SA}$ with $1.5 \%$ yuza powder). Untrained panelists were recruited via on and off-line advertisement and were asked to indicate their degree of liking, preference or acceptance of a product directly. The samples were served in random order to seventy untrained panelists to evaluate the sensory properties of color, smell, taste, and texture, as well as their overall preference for beef jerky containing yuza powder and the SL and SA mixtures. A 7-point hedonic scale was used to evaluate color, smell, texture, and overall preference ranging from 1, indicating extremely disliked to 7 , indicating extremely liked. In addition, taste (bitterness and sweetness) was also evaluated on a 7-point scale, where 1 indicated no taste at all and 7 indicated a strong taste.

\subsection{Statistical Analyses}

All experiments were performed at least twice. The significance of the differences between the sample treatments was measured by one-way ANOVA, followed by Duncan's multiple range test $(p<0.05)$ using the SAS program (version 9.3, SAS Institute, Inc., Cary, NC, USA).

\section{Result and Discussion}

\subsection{Effect of Water Activity and the Mixture of Sodium Lactate and Sodium Acetate on the Fate of $S$, aureus in Beef Jerky}

Water activity affects the growth of bacteria. $S$. aureus may grow at $\mathrm{A}_{\mathrm{w}}$ values near 0.86 [22]. In order to investigate the effect of water activity and the SL and SA mixture on the behavior of $S$. aureus in beef jerky, 0.75 or $1 \%$ of the SL and SA mixture was added and the water activity of beef jerky was adjusted to 0.70 , 0.75 , and 0.80 and it was stored at $25^{\circ} \mathrm{C}$. The $S$. aureus population decreased in the original beef jerky, regardless of the $A_{w}$ values, and the reduction rate was affected by the water activity and the concentration of the SL and SA mixture (Figure 2).

The delta value of $S$. aureus was the lowest at $\mathrm{A}_{\mathrm{w}} 0.75$. The shape parameters $(p)$ of all samples at $25^{\circ} \mathrm{C}$ were $p>1$ (data not shown), which corresponded to downward concavity (Figure 2). This indicated that $S$. aureus in beef jerky displayed a long survival lag phase in the beginning but a rapid death at the end of 13 days of storage at $25^{\circ} \mathrm{C}$. Regardless of the presence of the SL and SA mixture, $S$. aureus in beef jerky at $\mathrm{A}_{\mathrm{w}} 0.70$ survived longer than that at $\mathrm{A}_{\mathrm{w}} 0.75$. According to the work by Ingham and others [23], S. aureus and L. monocytogenes in vacuum packaged beef jerky rapidly decreased at $A_{w} 0.87$ compared to $A_{w} 0.63$, suggesting that other factors, such as seasoning, smoke compounds, besides $A_{w}$ affected $S$. aureus behavior. A recent study reported that $S$. aureus grew in commercial aerobically packaged beef jerky with an $A_{w}$ of 0.78 at temperatures above $21^{\circ} \mathrm{C}[7]$.

In addition, the effect of the 5:5 mixture of SL and SA on $S$. aureus in beef 


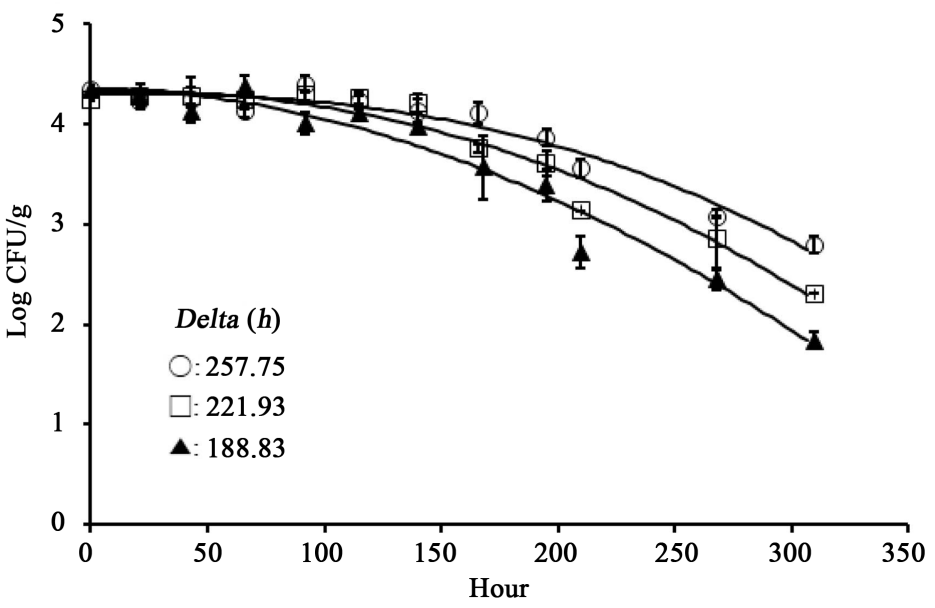

(a)

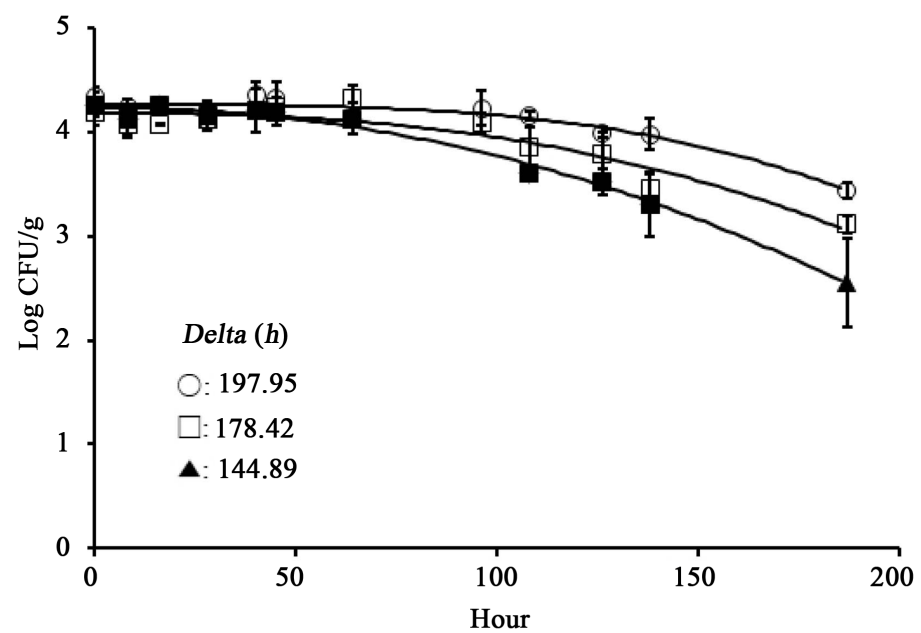

(b)

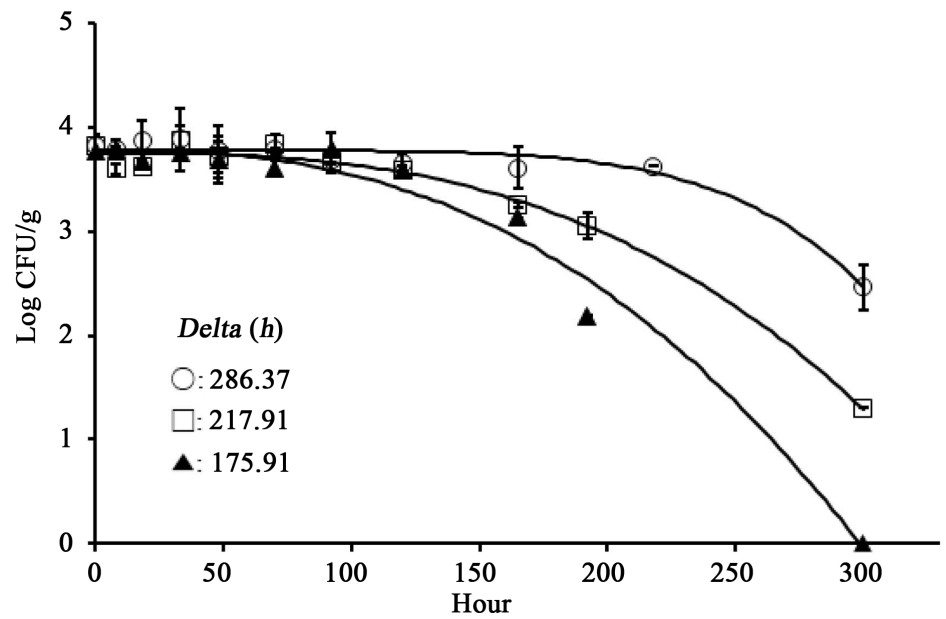

(c)

Figure 2. Effect of $A_{w}$ and the mixture of sodium lactate (SL) and sodium acetate (SA) on $S$. aureus survival in beef jerky at $25^{\circ} \mathrm{C}$. (a) $\mathrm{A}_{\mathrm{w}}$ 0.70; (b) $\mathrm{A}_{\mathrm{w}} 0.75$; (c) $\mathrm{A}_{\mathrm{w}} 0.80$; ○: control beef jerky without the mixture of SL and SA $\square$ : beef jerky containing $0.75 \%$ mixture of SL and SA $\boldsymbol{\Delta}$ : beef jerky containing $1.0 \%$ mixture of SL and SA. 
jerky was investigated at $25^{\circ} \mathrm{C}$. Regardless of the water activity, the delta and $p$ values were reduced as the concentration of the SL and SA mixture increased from 0.75 to $1 \%$, indicating that the SL and SA mixture had an antimicrobial effect on $S$. aureus in beef jerky. The SL and SA mixture prevented the growth of Listeria monocytogenes in ready-to-eat meat products at $4^{\circ} \mathrm{C}$ for three months [24]. Most previous studies on the antimicrobial effect of lactate and diacetate have concentrated on $L$. monocytogenes in meat products. Since beef jerky is manufactured by a manual process, the risk of $S$. aureus due to cross-contamination during manufacturing should not be ignored and control measures for the safety of beef jerky must be implemented during the manufacturing process.

\subsection{Effect of Water Activity and The mixture of Sodium Lactate and Sodium Acetate on the Fate of A. flavus in Beef Jerky}

In the commercial market, various beef jerkies are sold in aerobic or anaerobic packages and, thus, fungal growth occurs easily in aerobically packaged jerky [8]. Nitrite is added to jerky to control bacterial growth [25]. However, nitrites do not prevent the growth of fungi [11]. In this study, the ability of $\mathrm{A}_{\mathrm{w}}$ and the SL and SA mixture to control the growth of $A$. flavus in beef jerky at $25^{\circ} \mathrm{C}$ for four weeks was investigated (Figure 3 ). The growth of $A$. flavus in beef jerky containing the SL and SA mixture was inhibited at $25^{\circ} \mathrm{C}$ for four weeks, regardless of the $A_{w}$, indicating that addition of the SL and SA mixture to beef jerky had an antifungal effect. Without the SL and SA mixture, at $\mathrm{A}_{\mathrm{w}}$ above 0.75 , the growth of $A$. flavus in beef jerky lagged for 2 weeks, then increased over $6 \log \mathrm{CFU} / \mathrm{g}$, while the growth of $A$. flavus was not observed for four weeks at $\mathrm{A}_{\mathrm{w}} 0.70$. The synergistic effect of a low $\mathrm{A}_{\mathrm{w}}$ and the SL and SA mixture on A. flavus inhibition was stronger than when water activity alone was varied or the SL and SA mixture alone was used to control the A. flavus growth. The results of this study indicate that the growth of $A$. flavus cannot be controlled only by adjusting water activity and that various techniques, such as temperature control and antifungal agents, must be used. A. flavus in jerky has also been controlled by vacuum packaging [10], radiation [10] and flexible thin-layer plasma [4]. The addition of sodium lactate, followed by storage at $4^{\circ} \mathrm{C}$ also inhibited the growth of mold and yeast in traditional meat products in Turkey [26]. The addition of $2 \%$ sodium lactate to vacuum packaged sausage inhibited the growth of mold and yeast for eight days at $8^{\circ} \mathrm{C}$ [27]. These results indicate that sodium lactate had an antifungal effect in these meats.

Samapundo and others [28] developed a model to predict the effect of water activity and temperature on $A$. flavus in PDA media. At $\mathrm{A}_{\mathrm{w}} 0.80$, no growth of $A$. flavus was observed at all temperatures tested $\left(16^{\circ} \mathrm{C}, 22^{\circ} \mathrm{C}, 25^{\circ} \mathrm{C}, 30^{\circ} \mathrm{C}\right.$ and $37^{\circ} \mathrm{C}$ ). Although $\mathrm{A}_{\mathrm{w}} 0.80$ inhibited the growth of $A$. flavus in PDA in the previous work, the growth of $A$. flavus in beef jerky without the SL and SA mixture was observed at $\mathrm{A}_{\mathrm{w}} 0.80$ in the present study. These results indicate that the risk of $A$. flavus in beef jerky was high. Thus, additional control measures are needed to prevent the growth of $A$. flavus in beef jerky. 

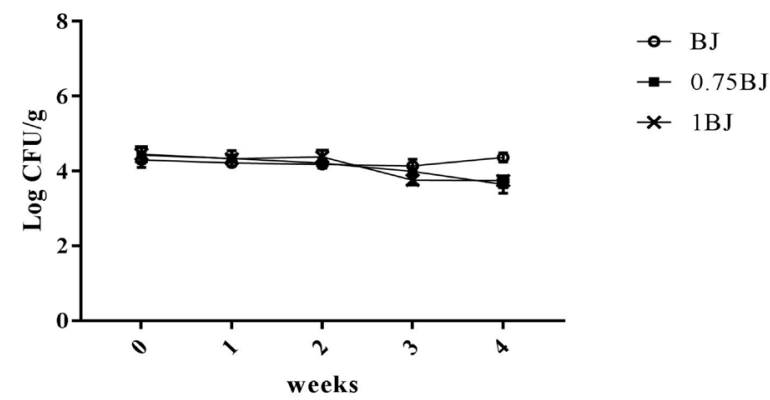

$* 1 \mathrm{BJ}$

(a)

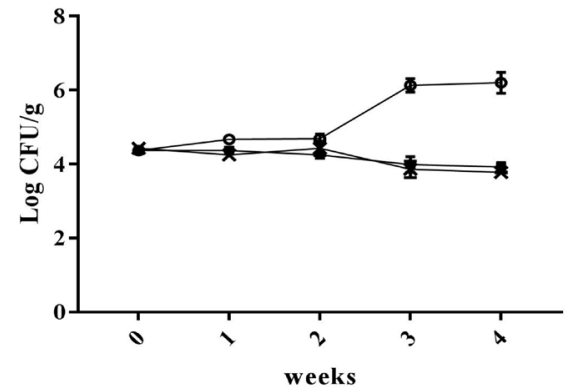

- $\mathrm{BJ}$

$-0.75 \mathrm{BJ}$

$\times \quad 1 \mathrm{BJ}$

(b)

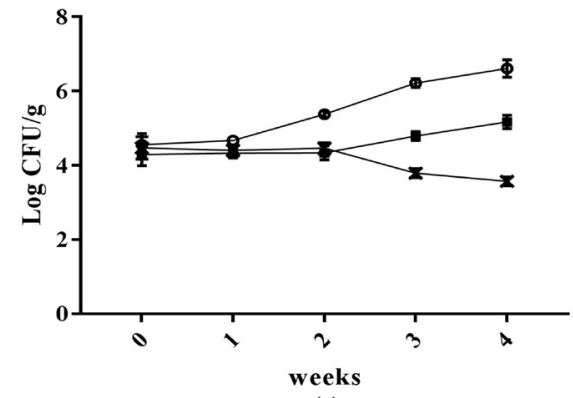

$\rightarrow$ BJ

$-0.75 \mathrm{BJ}$

$\times 1 \mathrm{BJ}$

(c)

Figure 3. Effect of $A_{w}$ and the mixture of sodium lactate (SL) and sodium acetate (SA) on A. flavus in beef jerky at $25^{\circ} \mathrm{C}$. (a) $\mathrm{A}_{\mathrm{w}} 0.70$; (b) $\mathrm{A}_{\mathrm{w}} 0.75$; (c) $\mathrm{A}_{\mathrm{w}} 0.80 \mathrm{BJ}$ : control beef jerky without mixture of SL and SA $0.75 \mathrm{BJ}$ : beef jerky containing $0.75 \%$ mixture of SL and SA $1 \mathrm{BJ}$ : beef jerky containing $1.0 \%$ mixture of SL and SA.

\subsection{Effect of Yuza Powder and the Mixture of Sodium Lactate and Sodium Acetate on the Fate of $S$, aureus in Beef Jerky at $10^{\circ} \mathrm{C}$ and $25^{\circ} \mathrm{C}$}

Yuza's peel and flesh residue have been tested in new product development investigations because of its numerous health benefits. In this work, the synergetic antimicrobial activity of yuza powder and the SL and SA mixture on $S$. aureus in beef jerky was investigated. Sliced beef was marinated with $1.5 \%$ yuza powder with and without the SL and SA mixture and was dried to adjust the water activity to 0.80 . The amount of $S$. aureus in prepared beef jerky was investigated at $10^{\circ} \mathrm{C}$ and $25^{\circ} \mathrm{C}$ (Table 1 ). The $S$. aureus population decreased more rapidly after the addition of the SL and SA mixture, regardless of the storage temperature. Without the SL and SA mixture, $S$. aureus in all beef jerky containing yuza powder survived well and had a long lag phase at both $10^{\circ} \mathrm{C}$ and $25^{\circ} \mathrm{C}$. The 
Table 1. Effect of yuza, temperature and the mixture of sodium lactate (SL) and sodium acetate (SA) on $S$. aureus survival in beef jerky at $10^{\circ} \mathrm{C}$ and $25^{\circ} \mathrm{C}$

\begin{tabular}{ccccc}
\hline Temperature & \multicolumn{2}{c}{$10^{\circ} \mathrm{C}$} & \multicolumn{2}{c}{$25^{\circ} \mathrm{C}$} \\
\hline Parameter & Delta $(\mathrm{h})$ & $p$ & Delta $(\mathrm{h})$ & $p$ \\
\hline YBJ & 645.29 & 3.54 & 201.47 & 3.35 \\
0.75 YBJ & 279.41 & 1.29 & 186.55 & 2.95 \\
1 YBJ & 253.99 & 1.64 & 157.42 & 2.34 \\
\hline
\end{tabular}

YBJ: control beef jerky containing yuza powder without the mixture of SL and SA, 0.75 YBJ: beef jerky containing yuza pwder and $0.75 \%$ mixture of SL and SA, 1 YBJ: beef jerky containing yuza powder and $1.0 \%$ mixture of SL and SA.

shortest delta values of $S$. aureus were observed in the $1.0 \%$ SL and SA mixture in beef jerky, which were accompanied by a long lag phase in the beginning, followed by a rapid death at the end of storage with a downward concave shape $(p>1)$. Overall, the populations of $S$ aureus in beef jerky decreased faster at $25^{\circ} \mathrm{C}$ compared to $10^{\circ} \mathrm{C}$, regardless of the presence of yuza powder or the SL and SA mixture. The worst condition for the survival of $S$. aureus was observed in beef jerky containing yuza powder and $1 \%$ SL and SA mixture at $25^{\circ} \mathrm{C}$. These results indicate that yuza powder had a synergetic antimicrobial effect with the SL and SA mixture. In commercial settings, beef jerky is sold at refrigerated or ambient temperatures. The settings at retail markets must be verified for the safety of beef jerky. The results of the present study showed that the addition of yuza powder and the SL and SA mixture to beef jerky decreased the populations of $S$. aureus at both $10^{\circ} \mathrm{C}$ and $25^{\circ} \mathrm{C}$ and, thus, reduced the risk of food poisoning that occurs from enterotoxin produced by $S$. aureus. Yuza peel consists of many compounds, such as limonene, hesperidin, and naringin [29]. Limonene has been shown to have an antimicrobial effect [30]. Although yuza contains these antimicrobial substances, studies on the antimicrobial properties of yuza have not been researched, unlike other citrus fruits. The results of this study showed that yuza can be used, not only as a flavor enhancer but also as an antimicrobial in processed meat products.

\subsection{Effect of Yuza Powder and the Mixture of Sodium Lactate and Sodium Acetate on A. flavus and Total Aflatoxin Production in Beef Jerky at $10^{\circ} \mathrm{C}$ and $25^{\circ} \mathrm{C}$}

In order to investigate to antifungal activity of yuza powder and the SL and SA mixture on A. flavus and aflatoxin production in beef jerky, A. flavus was inoculated into beef jerky containing $1.5 \%$ yuza powder and $0.75 \%$ or $1 \%$ SL and SA mixture. The jerky was stored for eight and four weeks at $10^{\circ} \mathrm{C}$ and $25^{\circ} \mathrm{C}$, respectively (Figure 4). No growth of A. flavus in the beef jerky containing yuza powder and $1 \% \mathrm{SL}$ and SA mixture was observed at $10^{\circ} \mathrm{C}$ for eight weeks, while the growth of $A$. flavus was not prevented at $25^{\circ} \mathrm{C}$. The growth of $A$. flavus was also prevented in beef jerky containing $1 \% \mathrm{SL}$ and SA mixture but the growth of A. flavus was not prevented with just yuza powder at $\mathrm{A}_{\mathrm{w}} 0.80$ (Figure 3). The 
$10^{\circ} \mathrm{C}$

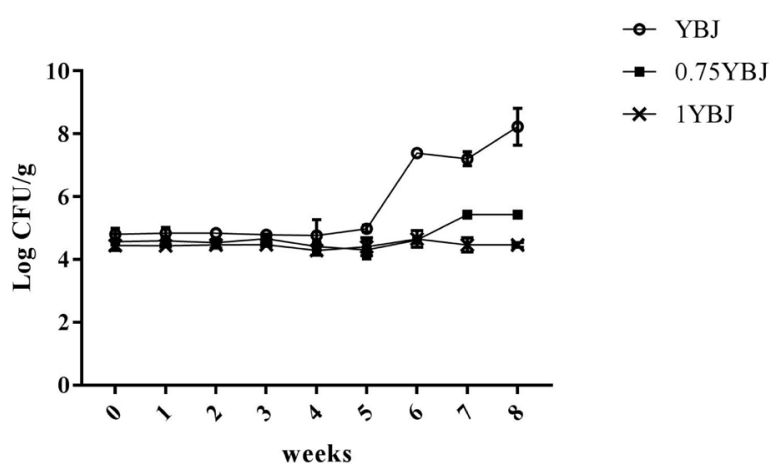

$25^{\circ} \mathrm{C}$

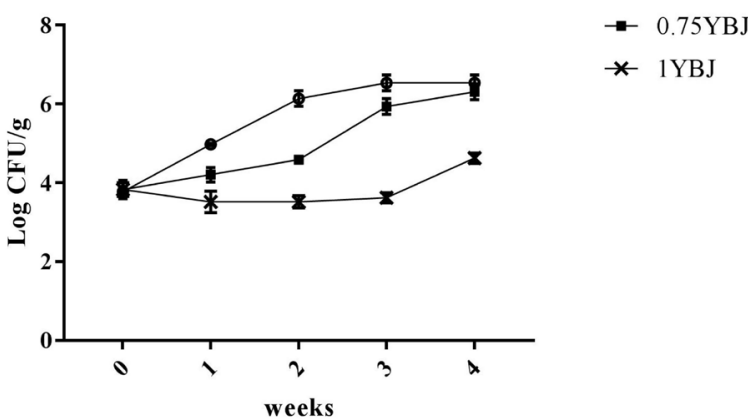

Figure 4. Effect of yuza and the mixture of sodium lactate (SL) and sodium acetate (SA) on $A$. flavus in beef jerky at $10^{\circ} \mathrm{C}$ and $25^{\circ} \mathrm{C}$. YBJ: control beef jerky containing yuza powder without the mixture of SL and SA, $0.75 \mathrm{YBJ}$ : beef jerky containing yuza pwder and $0.75 \%$ mixture of SL and SA, 1 YBJ: beef jerky containing yuza powder and $1.0 \%$ mixture of SL and SA.

most common cause of citrus fruit decay is mold [31]. In this work, the lag time of A. flavus in beef jerky containing just yuza powder without the SL and SA mixture was extended up to five weeks at $10^{\circ} \mathrm{C}$, indicating that storage at low temperature may decrease the risk of beef jerky due to the growth of A. flavus.

Aflatoxin production is affected by several environmental conditions, such as $\mathrm{A}_{w}, \mathrm{CO}_{2}$ levels, temperatures, and incubation times [32] [33]. These results indicate that the optimum conditions for aflatoxin production varied depending on the environment. Figure 5 shows the effects of $A_{w}$, yuza powder and the mixture of SL and SA on total aflatoxin production in beef jerky measured at $10^{\circ} \mathrm{C}$ for eight weeks and $25^{\circ} \mathrm{C}$ for four weeks. The water activity was the most important factor controlling aflatoxin production in beef jerky. Aflatoxin was not detected in any samples with an $A_{w}$ less than 0.75 (data not shown). However, the maximum accumulation of total aflatoxin (7.31 ppb) was observed in beef jerky without the SL and SA mixture at $A_{w} 0.80$. Although aflatoxin accumulation in original beef jerky significantly declined with increasing amounts of the SL and SA mixture $(0.75 \%$ and $1.0 \%)$ at $\mathrm{A}_{\mathrm{w}} 0.80$, the addition of the SL and SA mixture did not completely prevent aflatoxin production in beef jerky. These results suggest that the $A_{w}$ of beef jerky should be maintained at less than 0.75 to avoid aflatoxin accumulation. 


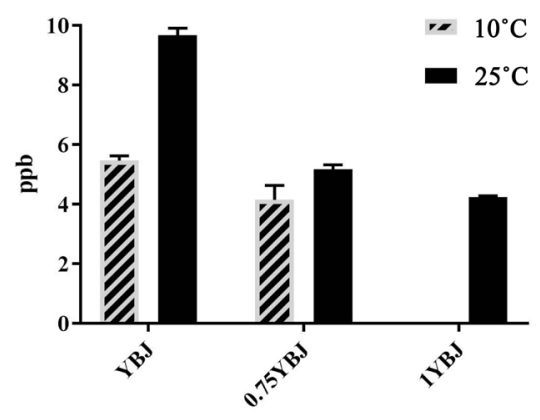

Figure 5. Effect of yuza powder and the mixture of sodium lactate (SL) and sodium acetate (SA) on aflatoxin production in beef jerky at $10^{\circ} \mathrm{C}$ and $25^{\circ} \mathrm{C}$. YBJ: control beef jerky containing yuza powder without the mixture of SL and SA, $0.75 \mathrm{YBJ}$ : beef jerky containing yuza pwder and $0.75 \%$ mixture of SL and SA, 1 YBJ: beef jerky containing yuza powder and $1.0 \%$ mixture of SL and SA.

Although there is risk of of aflatoxin in beef jerky, regulatory aflatoxin limits in many countries have not set. The regulatory limit of total aflatoxin in nuts is $20 \mathrm{ppb}$ in the US and Korea [34] [35]. In the present study, the total amount of aflatoxin in all beef jerkies was lower than the present regulatory limits for nuts of Korea. The range of water activity of commercial beef jerky in Korea has been reported to range from 0.70 to 0.83 [2] and aflatoxin may be produced during the shelf-life of beef jerky at Aw 0.80 or higher. Thus, regulations for the safe limit of water activity for beef jerky are needed and temperature control must be implemented at retail markets.

Figure 5 shows the effect of yuza powder and the SL and SA mixture on total aflatoxin in beef jerky at $\mathrm{A}_{\mathrm{w}} 0.80$ at $10^{\circ} \mathrm{C}$ and $25^{\circ} \mathrm{C}$. The growth of $A$. flavus in beef jerky proceeded for eight weeks at $10^{\circ} \mathrm{C}$ and four weeks at $25^{\circ} \mathrm{C}$. Then, when the storage period was over, the amount of aflatoxin in beef jerky was measured using the AgraQuant Aflatoxin Test Kit. There were significant differences in the amount of aflatoxin in the beef jerky samples that varied according to the concentration of the SL and SA mixture at both $10^{\circ} \mathrm{C}$ and $25^{\circ} \mathrm{C}$, regardless of the presence of yuza powder. No aflatoxin production was observed in beef jerky containing yuza powder and $1 \%$ SL and SA mixture after eight weeks of storage at $10^{\circ} \mathrm{C}$. However, aflatoxin production by $A$. flavus was not prevented in beef jerky with an $\mathrm{A}_{\mathrm{w}}$ of 0.80 at $25^{\circ} \mathrm{C}$, regardless of the presence of yuza powder and the SL and SA mixture, indicating that these additives were not effective to prevent aflatoxin production at ambient temperatures. According to the results of the present study, the $A_{w}$ of beef jerky must be adjusted to 0.75 to prevent aflatoxin production at ambient temperatures. Overall, the amount of aflatoxin produced in beef jerky was lower than that containing yuza powder at $25^{\circ} \mathrm{C}$, regardless of the addition of the sodium acetate and sodium lactate mixture of. Since more growth of $A$. flavus in beef jerky containing yuza powder was observed, more aflatoxin was detected. Beef jerky is commercially sold refrigerated or at ambient temperature, which is the optimal temperature for A. flavus growth and aflatoxin production [36]. Several studies have shown that the concentration of aflatoxin $B_{1}$ in sorghum seeds increased at $37^{\circ} \mathrm{C}$ compared to that 
at $25^{\circ} \mathrm{C}$ [33] and that aflatoxin $\mathrm{B}_{1}$ was produced by $A$. flavus on meat-based media at $25^{\circ} \mathrm{C}$ and small amounts were produced at $10^{\circ} \mathrm{C}$, regardless of the $\mathrm{A}_{\mathrm{w}}$ [37].

\subsection{Effect of Yuza Powder and the Mixture of Sodium Lactate and Sodium Acetate on the Color and Texture of Beef Jerky}

The effects of yuza powder and the SL and SA mixture on the color of beef jerky are shown in Table 2. Because brightness and redness of meat products are expected in meat products, the color of meat products is an important quality parameter. Addition of the SL and SA mixture significantly increased the lightness $\left(L^{*}\right)$, redness $\left(a^{*}\right)$, and yellowness $\left(b^{*}\right)$ of beef jerky $(p<0.05)$, regardless of the addition of yuza powder. The lightness of meat products is affected by many factors, including the concentration of additives [38], fiber content and type of meat products [39].

Figure 6 shows the effect of yuza powder and the SL and SA mixture on the texture of beef jerky. The hardness and chewiness of the beef jerky were affected

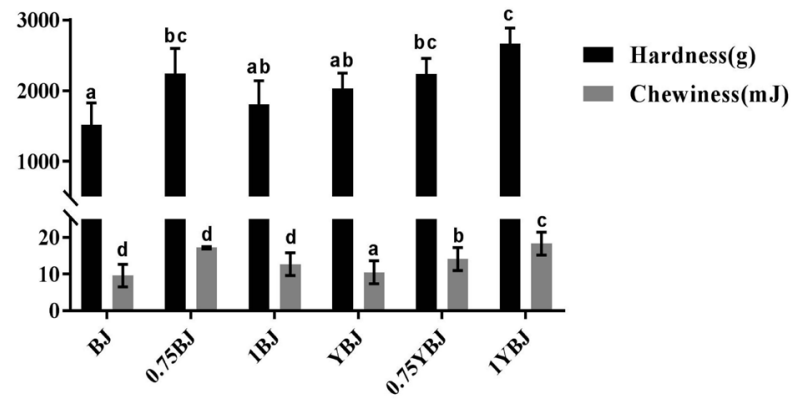

Figure 6. Effect of yuza powder on the texture characteristics of beef jerky at $A_{w} 0.80$. ${ }^{\mathrm{a}-\mathrm{e}}$ Means values in a row within different letters are significantly different by Duncan's multiple range test at $p<0.05$. BJ: control beef jerky without mixture of SL and SA, 0.75 BJ: beef jerky containing $0.75 \%$ mixture of SL and SA, 1 BJ: beef jerky containing $1.0 \%$ mixture of SL and SA, YBJ: control beef jerky containing yuza powder without the mixture of SL and SA, $0.75 \mathrm{YBJ}$ : beef jerky containing yuza pwder and $0.75 \%$ mixture of SL and SA, 1 YBJ: beef jerky containing yuza powder and 1.0\% mixture of SL and SA.

Table 2. Effect of yuza powder and the mixture of sodium lactate (SL) and sodium acetate (SA) on the color (Hunter's $L^{\star}, a^{\star}$ and $b^{\star}$ ) values of beef jerky.

\begin{tabular}{cccc}
\hline \multirow{2}{*}{ Color } & \multicolumn{3}{c}{ Beef jerky ${ }^{\mathrm{a}}$} \\
\cline { 2 - 4 } & $18.95 \pm 2.20^{\mathrm{a}}$ & $0.75 \%^{1)}$ & $1.0 \%$ \\
\hline$L^{*}$ & $5.49 \pm 1.23^{\mathrm{a}}$ & $21.41 \pm 1.39^{\mathrm{b}}$ & $22.94 \pm 2.46^{\mathrm{b}}$ \\
$a^{*}$ & $5.56 \pm 1.07^{\mathrm{a}}$ & $8.82 \pm 1.65^{\mathrm{b}}$ & $8.54 \pm 1.17^{\mathrm{b}}$ \\
$b^{*}$ & & $7.77 \pm 1.28^{\mathrm{b}}$ & $8.69 \pm 2.44^{\mathrm{c}}$ \\
& $0 \%$ & Beef jerky with yuza powder & \\
& $20.41 \pm 2.03^{\mathrm{a}}$ & $0.75 \%^{1)}$ & $1.0 \%$ \\
$L^{*}$ & $7.85 \pm 2.53^{\mathrm{a}}$ & $22.44 \pm 2.14^{\mathrm{b}}$ & $24.29 \pm 1.98^{\mathrm{b}}$ \\
$a^{*}$ & $9.29 \pm 3.12^{\mathrm{a}}$ & $8.32 \pm 1.94^{\mathrm{b}}$ & $9.36 \pm 1.74^{\mathrm{c}}$ \\
$b^{*}$ & $9.36 \pm 2.45^{\mathrm{a}}$ & $10.65 \pm 1.58^{\mathrm{b}}$ \\
\hline
\end{tabular}

${ }^{1)}$ Concentration of mixture sodium lactate and sodium acetate. ${ }^{\mathrm{a}-\mathrm{c}}$ Means values $(\mathrm{n}=3)$ in a row within different letters are significantly different by Duncan's multiple range test at $p<0.05$. 
by yuza powder and the SL and SA mixture. Beef jerky containing yuza powder was harder than beef jerky without yuza powder, indicating that the addition of yuza powder in beef jerky affected the hardness. The addition of the SL and SA mixture to beef jerky containing yuza powder significantly increased the hardness and chewiness $(p<0.05)$. In the previous study, the addition of orange dietary fiber to sausage increased hardness by intensifying protein matrix formation during cooking [40]. Bologna sausage with orange, apple, and peach fiber have shown the same results [41].

\subsection{Effect of Yuza Powder and the Mixture of Sodium Lactate and Sodium Acetate on the Sensory Scores of Beef Jerky}

In order to test the taste preference for beef jerky containing yuza powder and the SL and SA mixture, color, flavor, sweetness, bitterness, texture, and overall acceptability were evaluated by 70 non-trained panelists (Table 3). Overall, no significant differences were observed in the beef jerky with or without yuza powder and the SL and SA mixture. However, the parameters of sweetness and bitterness were significantly affected by the yuza powder, regardless of the addition of the SL and SA mixture. The addition of yuza powder to beef jerky reduced sweetness and increased bitterness, indicating that sweetness and bitterness might be affected by the unique taste and flavor of yuza powder. However, the change was very minimal and other sensory characteristics were not affected.

\section{Conclusion}

The results from this study demonstrated the antimicrobial effect of yuza powder and the SL and SA mixture in beef jerky. However, the growth of $S$. aureus was not controlled in beef jerky with an $\mathrm{A}_{\mathrm{w}}$ 0.80. In addition, yuza powder was not very effective in controlling the growth of A. flavus in beef jerky but the growth of $A$. flavus was controlled by the addition of $1 \%$ SL and SA mixture and

Table 3. The sensory scores of color, flavor, texture, overall acceptability and sweetness and bitterness of the beef jerkies.

\begin{tabular}{ccccc}
\hline \multirow{2}{*}{ Sensory parameters $^{1)}$} & \multicolumn{4}{c}{ Samples } \\
\cline { 2 - 5 } & BJ & $1 \mathrm{BJ}$ & YBJ & 1 YBJ \\
\hline Color & $5.14 \pm 1.13^{\mathrm{a}}$ & $5.19 \pm 1.31^{\mathrm{a}}$ & $4.91 \pm 1.40^{\mathrm{a}}$ & $4.77 \pm 1.37^{\mathrm{a}}$ \\
Flavor & $4.80 \pm 1.50^{\mathrm{a}}$ & $4.71 \pm 1.47^{\mathrm{a}}$ & $4.60 \pm 1.63^{\mathrm{a}}$ & $5.06 \pm 1.52^{\mathrm{a}}$ \\
Texture & $4.04 \pm 1.78^{\mathrm{a}}$ & $4.11 \pm 1.72^{\mathrm{a}}$ & $4.64 \pm 1.63^{\mathrm{a}}$ & $4.34 \pm 1.71^{\mathrm{a}}$ \\
Overall acceptability & $4.86 \pm 1.52^{\mathrm{a}}$ & $5.09 \pm 1.59^{\mathrm{a}}$ & $4.69 \pm 1.48^{\mathrm{a}}$ & $4.80 \pm 1.48^{\mathrm{a}}$ \\
Sweetness & $5.20 \pm 1.36^{\mathrm{b}}$ & $5.13 \pm 1.27^{\mathrm{b}}$ & $4.61 \pm 1.39^{\mathrm{a}}$ & $4.54 \pm 1.44^{\mathrm{a}}$ \\
Bitterness & $2.50 \pm 1.98^{\mathrm{a}}$ & $2.46 \pm 1.86^{\mathrm{a}}$ & $2.96 \pm 1.93^{\mathrm{ab}}$ & $3.20 \pm 1.93^{\mathrm{b}}$ \\
\hline
\end{tabular}

${ }^{1)}$ Evaluated on a 7-point hedonic scale from $1=$ disliked extremely to $7=$ liked extremely. ${ }^{\text {a-b }}$ Means values ( $\mathrm{n}$ $=70$ ) in a row within different letters are significantly different by Duncan's multiple range test at $p<0.05$. BJ: control beef jerky without the mixture of SL and SA, 1 BJ: beef jerky containing 1.0\% mixture of SL and SA. YBJ: control beef jerky containing yuza powder without the mixture of SL and SA, 1 YBJ: beef jerky containing yuza powder and $1.0 \%$ mixture of SL and SA. 
storage at $10^{\circ} \mathrm{C}$. Water activity was the most important factor shown to control aflatoxin production in beef jerky. Since aflatoxin was produced in all beef jerky with an $A_{w}$ of 0.80 , the safe $A_{w}$ level of jerky in Korea $(0.70-0.83)$ must be reevaluated. The quality of beef jerky was also affected by the $A_{w}$, yuza powder, and the SL and SA mixture. Color parameters $\left(L^{\star}, a^{\star}, b^{\star}\right)$ were also enhanced by the addition of yuza powder and the SL and SA mixture. Hardness was increased by the addition of yuza powder. With the exception of sweetness and bitterness, no significant differences in sensory scores of the beef jerkies were observed between those with and without yuza powder. Scores for sweetness and bitterness of the beef jerkies containing yuza powder were higher than those of the other beef jerkies. The results of the present study indicate that yuza powder may be used as a new ingredient to create new tastes of beef jerky.

\section{Conflicts of Interest}

The authors declare no conflicts of interest regarding the publication of this paper.

\section{References}

[1] Yang, H., Hwang, Y., Joo, S. and Park, G. (2009) The Physicochemical and Microbiological Characteristics of Pork Jerky in Comparison to Beef Jerky. Meat Science, 82, 289-294. https://doi.org/10.1016/j.meatsci.2009.01.029

[2] Park, S., Shim, Y., Joeng, S., Lee, H.S. and Kim, J. (2016) Investigation of Quality Properties of Commercial Jerky from Korean Market for Establishment of Quality Parameters. Journal of the East Asian Society of Dietary Life, 26, 230-236. https://doi.org/10.17495/easdl.2016.6.26.3.230

[3] USDA (2004) Beef Jerky Guide Line. https://www.fsis.usda.gov/wps/portal/fsis/topics/rulemaking/!ut/p/a0/04_Sj9CPykss y0xPLMnMz0vMAfGjzOINAg3MDC2dDbz83RzdDDz9jN3CLPzcDQ28TfULsh0V AdZTe2c!/?1dmy\&current=true\&urile=wcm\%3Apath\%3A\%2Ffsis-archives-content \%2Finternet\%2Fmain\%2Ftopics\%2Frecalls-and-public-healthalerts\%2Frecall-case-a rchive $\% 2$ Farchives $\% 2$ Fct_index $212 \mathrm{a}$

[4] Yong, H.I., Lee, H., Park, S., Park, J., Choe, W., Jung, S. and Jo, C. (2017) Flexible Thin-Layer Plasma Inactivation of Bacteria and Mold Survival in Beef Jerky Packaging and Its Effects on the Meat's Physicochemical Properties. Meat Science, 123, 151-156. https://doi.org/10.1016/j.meatsci.2016.09.016

[5] Dierschke, S., Ingham, S.C. and Ingham, B.H. (2010) Destruction of Escherichia coli O157: H7, Salmonella, Listeria monocytogenes, and Staphylococcus aureus Achieved during Manufacture of Whole-Muscle Beef Jerky in Home-Style Dehydrators. Journal of Food Protection, 73, 2034-2042. https://doi.org/10.4315/0362-028X-73.11.2034

[6] Kim, J., Lee, E., Choi, E.H. and Kim, Y. (2014) Inactivation of Staphylococcus aureus on the Beef Jerky by Radio-Frequency Atmospheric Pressure Plasma Discharge Treatment. Innovative Food Science \& Emerging Technologies, 22, 124-130. https://doi.org/10.1016/j.ifset.2013.12.012

[7] Kim, Y.H., Nam, G.W. and Yoon, K.S. (2018) Growth and Survival of Staphylococcus aureus on Beef Jerky as a Function of Temperature. Journal of Food Safety, 38, e12495. https://doi.org/10.1111/jfs.12495 
[8] Clavero, R. (2010) Solving Microbial Spoilage Problems in Processed Foods. In: Anonymous Principles of Microbiological Troubleshooting in the Industrial Food Processing Environment, Springer, Berlin, 63-78. https://doi.org/10.1007/978-1-4419-5518-0_3

[9] Rojas, F., Jodral, M., Gosalvez, F. and Pozo, R. (1991) Mycoflora and Toxigenic Aspergillus flavus in Spanish Dry-Cured Ham. International Journal of Food Microbiology, 13, 249-255. https://doi.org/10.1016/0168-1605(91)90082-Z

[10] Lee, J., Kim, D., Oh, S., Kim, J., Oh, S., Lee, Y. and Byun, M. (2004) Radiation Sensitivity of Aspergillus flavus in Semi-Dried Beef Jerky. Food Science and Biotechnology, 13, 613-615.

[11] Lück, E. and Jager, M. (1997) Antimicrobial Food Additives: Characteristics, Uses, Effects. Springer Science \& Business Media, Berlin. https://doi.org/10.1007/978-3-642-59202-7

[12] Moon, S.H., Derbie Assefa, A., Ko, E.Y. and Park, S.W. (2015) Comparison of Flavonoid Contents and Antioxidant Activity of Yuzu (Citrus junos Sieb. ex Tanaka) Based on Harvest Time. Korean Journal of Horticultural Science \& Technology, 33, 283-291. https://doi.org/10.7235/hort.2015.14180

[13] Yoon, M., Seo, J., Ryu, G., Kim, Y., Seo, M. and Chang, Y.H. (2016) Physicochemical, Microbial, Rheological, and Sensory Properties of Yogurt Added with Yuza Pectin Extract. Journal of the Korean Society of Food Science and Nutrition, 45, 562-568. https://doi.org/10.3746/jkfn.2016.45.4.562

[14] von Woedtke, T., Schluter, B., Pflegel, P., Lindequist, U. and Julich, W.D. (1999) Aspects of the Antimicrobial Efficacy of Grapefruit Seed Extract and Its Relation to Preservative Substances Contained. Die Pharmazie, 54, 452-456.

[15] Liang, Z., Mittal, G.S. and Griffiths, M.W. (2002) Inactivation of Salmonella Typhimurium in Orange Juice Containing Antimicrobial Agents by Pulsed Electric Field. Journal of Food Protection, 65, 1081-1087. https://doi.org/10.4315/0362-028X-65.7.1081

[16] Corbion (2019) OptiForm Powder Ace S50 Information. https://www.corbion.com/search?mainFilter $=$ \&highlight=\&page $=1 \&$ keywords $=\mathrm{Opt}$ i.Form + powder+ace+S50

[17] Stekelenburg, F. (2003) Enhanced Inhibition of Listeria monocytogenes in Frankfurter Sausage by the Addition of Potassium Lactate and Sodium Diacetate Mixtures. Food Microbiology, 20, 133-137. https://doi.org/10.1016/S0740-0020(02)00098-9

[18] Vogel, B.F., Ng, Y.Y., Hyldig, G., Mohr, M. and Gram, L. (2006) Potassium Lactate Combined with Sodium Diacetate Can Inhibit Growth of Listeria monocytogenes in Vacuum-Packed Cold-Smoked Salmon and Has No Adverse Sensory Effects. Journal of Food Protection, 69, 2134-2142. https://doi.org/10.4315/0362-028X-69.9.2134

[19] Lianou, A., Geornaras, I., Kendall, P.A., Scanga, J.A. and Sofos, J.N. (2007) Behavior of Listeria monocytogenes at $7 \mathrm{C}$ in Commercial Turkey Breast, with or without Antimicrobials, after Simulated Contamination for Manufacturing, Retail and Consumer Settings. Food Microbiology, 24, 433-443.

https://doi.org/10.1016/j.fm.2006.11.002

[20] Albert, I. and Mafart, P. (2005) A Modified Weibull Model for Bacterial Inactivation. International Journal of Food Microbiology, 100, 197-211. https://doi.org/10.1016/j.ijfoodmicro.2004.10.016

[21] Bourne, M. (1978) Texture Profile Analysis [Food Acceptability]. Food Technology.

[22] Jay, J.M. (2012) Modern Food Microbiology. Springer Science \& Business Media, 
Berlin.

[23] Ingham, S.C., Searls, G., Mohanan, S. and Buege, D.R. (2006) Survival of Staphylococcus aureus and Listeria monocytogenes on Vacuum-Packaged Beef Jerky and Related Products Stored at 21 C. Journal of Food Protection, 69, 2263-2267. https://doi.org/10.4315/0362-028X-69.9.2263

[24] Thompson, R., Carpenter, C., Martini, S. and Broadbent, J.R. (2008) Control of Listeria monocytogenes in Ready-to-Eat Meats Containing Sodium Levulinate, Sodium Lactate, or a Combination of Sodium Lactate and Sodium Diacetate. Journal of Food Science, 73, M239-M244. https://doi.org/10.1111/j.1750-3841.2008.00786.x

[25] Sofos, J.N., Busta, F.F. and Allen, C. (1979) Botulism Control by Nitrite and Sorbate in Cured Meats: A Review. Journal of Food Protection, 42, 739-770. https://doi.org/10.4315/0362-028X-42.9.739

[26] Bingol, E.B., Colak, H., Cetin, O. and Hampikyan, H. (2014) Effects of Sodium Lactate on the Shelf Life and Sensory Characteristics of Cig Kofte-A Turkish Traditional Raw Meatball. Journal of Food Processing and Preservation, 38, 1024-1036. https://doi.org/10.1111/jfpp.12059

[27] Brasileiro, I.S., Barbosa, M., Igarashi, M.C., Biscola, V., Maffei, D.F., Landgraf, M. and de Melo Franco, B.D.G. (2016) Use of Growth Inhibitors for Control of Listeria monocytogenes in Heat-Processed Ready-to-Eat Meat Products Simulating PostProcessing Contamination. LWT_Food Science and Technology, 74, 7-13. https://doi.org/10.1016/j.lwt.2016.06.069

[28] Samapundo, S., Devlieghere, F., Geeraerd, A., De Meulenaer, B., Van Impe, J. and Debevere, J. (2007) Modelling of the Individual and Combined Effects of Water Activity and Temperature on the Radial Growth of Aspergillus flavus and A. parasiticus on Corn. Food Microbiology, 24, 517-529. https://doi.org/10.1016/j.fm.2006.07.021

[29] Zang, L., Shimada, Y., Kawajiri, J., Tanaka, T. and Nishimura, N. (2014) Effects of Yuzu (Citrus junos Siebold ex Tanaka) Peel on the Diet-Induced Obesity in a Zebrafish Model. Journal of Functional Foods, 10, 499-510. https://doi.org/10.1016/j.jff.2014.08.002

[30] Aggarwal, K., Khanuja, S., Ahmad, A., Santha Kumar, T., Gupta, V.K. and Kumar, S. (2002) Antimicrobial Activity Profiles of the Two Enantiomers of Limonene and Carvone Isolated from the Oils of Mentha spicata and Anethum sowa. Flavour and Fragrance Journal, 17, 59-63. https://doi.org/10.1002/ffj.1040

[31] Kanetis, L., Förster, H. and Adaskaveg, J.E. (2007) Comparative Efficacy of the New Postharvest Fungicides Azoxystrobin, Fludioxonil, and Pyrimethanil for Managing Citrus Green Mold. Plant Disease, 91, 1502-1511. https://doi.org/10.1094/PDIS-91-11-1502

[32] Mousa, W., Ghazali, F.M., Jinap, S., Ghazali, H.M., Radu, S. and Salama, A.E. (2016) Temperature, Water Activity and Gas Composition Effects on the Growth and Aflatoxin Production by Aspergillus flavus on Paddy. Journal of Stored Products Research, 67, 49-55. https://doi.org/10.1016/j.jspr.2016.01.003

[33] Lahouar, A., Marin, S., Crespo-Sempere, A., Said, S. and Sanchis, V. (2016) Effects of Temperature, Water Activity and Incubation Time on Fungal Growth and Aflatoxin B1 Production by Toxinogenic Aspergillus flavus Isolates on Sorghum Seeds. Revista Argentina de Microbiologia, 48, 78-85. https://doi.org/10.1016/j.ram.2015.10.001

[34] MFDS (2017) Regularly Limit of Total Aflatoxin. http://www.foodsafetykorea.go.kr/portal/safefoodlife/food/foodRvlv/foodRvlv.do 
[35] USDA (2017) Regularly Limit of Total Aflatoxin. https://www.fda.gov/ICECI/ComplianceManuals/CompliancePolicyGuidanceManu al/ucm119194.htm

[36] Klich, M.A. (2007) Environmental and Developmental Factors Influencing Aflatoxin Production by Aspergillus flavus and Aspergillus parasiticus. Mycoscience, 48, 71-80. https://doi.org/10.1007/S10267-006-0336-2

[37] Peromingo, B., Rodríguez, A., Bernáldez, V., Delgado, J. and Rodríguez, M. (2016) Effect of Temperature and Water Activity on Growth and Aflatoxin Production by Aspergillus flavus and Aspergillus parasiticus on Cured Meat Model Systems. Meat Science, 122, 76-83. https://doi.org/10.1016/j.meatsci.2016.07.024

[38] Lindahl, G., Lundström, K. and Tornberg, E. (2001) Contribution of Pigment Content, Myoglobin Forms and Internal Reflectance to the Colour of Pork Loin and Ham from Pure Breed Pigs. Meat Science, 59, 141-151.

https://doi.org/10.1016/S0309-1740(01)00064-X

[39] Fernández-Ginés, J., Fernández-López, J., Sayas-Barberá, E., Sendra, E. and PérezAlvarez, J. (2003) Effect of Storage Conditions on Quality Characteristics of Bologna Sausages Made with Citrus Fiber. Journal of Food Science, 68, 710-714. https://doi.org/10.1111/j.1365-2621.2003.tb05737.x

[40] Viuda-Martos, M., Ruiz-Navajas, Y., Fernández-López, J. and Pérez-Álvarez, J. (2010) Effect of Orange Dietary Fibre, Oregano Essential Oil and Packaging Conditions on Shelf-Life of Bologna Sausages. Food Control, 21, 436-443. https://doi.org/10.1016/j.foodcont.2009.07.004

[41] García, M.L., Caceres, E. and Selgas, M.D. (2007) Utilisation of Fruit Fibres in Conventional and Reduced-Fat Cooked-Meat Sausages. Journal of the Science of Food and Agriculture, 87, 624-631. https://doi.org/10.1002/jsfa.2753 